\title{
The Effects of Plant-Soil-Enzyme Interactions on Plant Composition, Biomass and Diversity of Alpine Meadows in the Qinghai-Tibetan Plateau
}

\author{
Changting Wang, ${ }^{1,2}$ Genxu Wang, ${ }^{3}$ Wei Liu, ${ }^{2}$ and Pengfei Wu ${ }^{1}$ \\ ${ }^{1}$ College of Life Science and Technology, Southwest University for Nationalities, Chengdu 610041, China \\ ${ }^{2}$ Northwest Plateau Institute of Biology, The Chinese Academy of Science, Xining 810001, China \\ ${ }^{3}$ Institute of Mountain Hazards and Environment, The Chinese Academy of Science, Chengdu 610041, China
}

Correspondence should be addressed to Changting Wang,wcht6@hotmail.com

Received 2 November 2010; Revised 12 January 2011; Accepted 4 March 2011

Academic Editor: Johannes Antonius van Veen

Copyright ( $) 2011$ Changting Wang et al. This is an open access article distributed under the Creative Commons Attribution License, which permits unrestricted use, distribution, and reproduction in any medium, provided the original work is properly cited.

\begin{abstract}
Four different alpine meadow communities were studied to examine the effects of plant-soil-enzyme interactions on plant composition and diversity. Enzyme activities differed by meadow type, and in general were higher in the upper soil layers (010 and $10-20 \mathrm{~cm}$ ) than in the $20-40 \mathrm{~cm}$ layer. Community differences in plant composition or functional group composition were reflected in plant biomass distribution. The identity of a species (or a functional group) was a greater determinant of ecosystem function than the number of plant species. A significant correlation was found between the coverage per functional group and the aboveground biomass of functional groups in four alpine meadows. Soil microbial biomass carbon $\left(C_{\mathrm{mic}}\right)$ and enzyme activity were each affected by both functional group biomass and $C A B$ in the different meadow types. The negative correlation between diversity and $C A B$ in the KTS may be influenced by a high soil nutrients input as a result of a higher litter input because of high aboveground biomass. Soil enzyme activities have been related to soil physio-chemical characters and plant primary production to change in vegetation. The original soil conditions, plant community composition, and community productivity are very important in regulating plant community productivity and microbial biomass and activity.
\end{abstract}

\section{Introduction}

Although the organisms living in an ecosystem control its functioning [1], it is unclear how much of this control is determined by the identities of the species [2], the number of species present $[2,3]$, and the number of different functional roles that these species represent [3]. Tilman [4] suggested that ecosystem processes were determined primarily by the functional characteristics of component organisms rather than by the number of individuals or species. Reich et al. $[5,6]$ indicated that species richness and functional group richness independently influence biomass accumulation and its response to elevated $\mathrm{CO}_{2}$ and $\mathrm{N}$. The functions of ecosystems and communities are not only related to the functional characteristics of the dominant species, but also to species number. However, the relative effects attributable to functional diversity versus functional composition are unclear.
Plant-soil feedback is the phenomenon by which a plant influences biotic or abiotic properties of the rhizosphere which, in turn, influences the performance of that individual or another plant [7]. Heterotrophic microbial communities inhabiting the soil mediate key processes that control ecosystem $\mathrm{C}, \mathrm{N}, \mathrm{P}$, and S cycling, and they potentially represent a mechanistic link between plant diversity and ecosystem function [8]. Mediation of niche differentiation for plant resource use as well as feedback dynamics between plant and soil communities have emerged as key areas of microbial influence on plant community structure and dynamics [9]. The availability of growth-limiting resources shapes the composition of plant communities [10], and resource availability for soil microbial communities is constrained by organic compounds in dead leaves and roots (i.e., detritus) that can be used to generate cellular energy [11]. Changes in the composition of plant species (or of functional groups) modify resource availability for heterotrophic microbial 
communities in the soil, which, in turn, also modifies their composition and function. These changes in microbial community composition and function will then directly influence the rates of carbon and nitrogen soil cycling [8]. Soil enzymes play key roles in the biochemical functioning of soils, including soil organic matter production, the decomposition of xenobiotics [12], and the cycling of nutrients such as carbon (invertase), nitrogen (urease and protease), and phosphorus (phosphatase). Soil enzyme activities are used as indices of microbial activity [13] and react quickly to changes in environmental conditions [14] and microbial community structure $[15,16]$ and vegetation [17].

Located in the center of the Qinghai-Tibetan Plateau; the "roof" of the world, the headwater area of three major rivers in Asia, the Yangtze River, Yellow River, and LancangMekong River is one of the important ecoregions in China and even in the world. Among 18.9 million $\mathrm{km}^{2}$ of total land in this area, over $85 \%$ is covered by alpine grasslands (including alpine meadow, alpine shrub-meadow and alpine steppe) and is grazed by livestock, such as yak, and indigenous herbivores, such as Tibetan sheep [18]). The grasslands in this area have served as the dominant pastures for Tibetan communities over a long history and are regarded as one of the major pastoral production bases in China [19]. They have also provided great ecosystem function and services such as carbon sequestration, biodiversity conservation, soil and water protection, Tibetan culture, and tradition carrying, through maintaining stable vegetation and soil systems, good genetic pool, high vegetation cover, and coupled sociocultural, and natural system [20]. However, degradation of alpine grasslands is limiting the sustainable development of ecological, social and economic systems at local and regional scales [19]. Grassland productivity and degradation are correlated with precipitation and temperature [21, 22]. Grassland protection and restoration has also been affected by climate condition and management status $[23,24]$. The original soil conditions, plant community composition, and community productivity are very important in regulating plant community productivity and microbial biomass and activity [25]. Thus, to understand the effects of plantmicrobe-soil-enzyme interactions in contributing to changes in different alpine meadows community structure, species diversity, and biomass, it is necessary to grassland restoration and to its sustainable development.

In this study, our objectives were to (1) study the relationship between microbial biomass, soil enzyme activity, and plant aboveground biomass; (2) determine whether an increase in plant aboveground biomass is associated with greater plant species richness or functional group number; (3) assess whether community aboveground biomass correlates with soil chemical properties or soil enzyme activities.

\section{Materials and Methods}

2.1. Study Site. The study was conducted at Haibei Research Station, which is operated by the Chinese Academy of Sciences, in August of 2003, 2004, and 2005. The Station is located at $37^{\circ} 32^{\prime} \mathrm{N}, 101^{\circ} 15^{\prime} \mathrm{E}$, at an altitude of $3240 \mathrm{~m}$ above sea level. The average annual precipitation recorded at the Station from 1976 to 2001 was $560 \mathrm{~mm}$, with $85 \%$ of that rainfall occurring within the growing season from May to September. The average annual air temperature for the 25 years from 1976 to 2001 was $-1.7^{\circ} \mathrm{C}$ [26]. Soils at the study site were classified as Mat-Cryic Cambisols, MolCryic Cambisols, and Organic Cryic Gleysols, according to the Chinese Soil Classification [27]. Alpine K. species were the dominant type of vegetation in the alpine meadow, which is one of the most important meadow types in the Qinghai-Tibetan Plateau. This region could be divided into four subtypes in our study sites: K. humilis meadow (KHM), K. pygmaea meadow (KPM), K. tibetica swamp meadow (KTS) and Potentilla fruticosa scrub (PFS). In the KHM community, species richness is high, with 25-35 species per $1 \mathrm{~m}^{2}$, with mesophilous species predominating. The dominant species are K. humilis, K. capillifolia, and Carex atrofusca, with many accompanying species, such as Poa polygonum and Festuca modesta. The grass community usually has 1-2 layers, with a height of $45-60 \mathrm{~cm}$ for the highest grass and an overall cover of $60-95 \%$. The KTS community is dominated by hygrophytes and mesohydrophytes such as K. tibetica, Blysmus sinacompressus, and Carex scabriostris. The accompanying species include Carex atrofusca and Saussurea stella, and species richness is 10-20 species per $1 \mathrm{~m}^{2}$. The grass community usually has 1 layer, with an average height of $10-25 \mathrm{~cm}$ and an overall cover of $80-95 \%$. The KPM community is dominated by perennial, frigid, mesophilous and xerophilous species such as K. pygmaea, Stipa aliena, and Stipa purpurea, with some important accompanying species such as Festuca ovina, Poa alpina, Saussurea superba and Potentilla bifurca. Species richness is 20-30 species per $1 \mathrm{~m}^{2}$. The grass community usually has two layers, with a height of $25-55 \mathrm{~cm}$ for the highest grass and an overall cover of $80-90 \%$. The PFS consists of perennial, frigid, and mesophilous shrubby species, with 20-35 species per $1 \mathrm{~m}^{2}$. The dominant species are Potentilla fruticosa, Salix oritrepha, Sibiraea angustata, and Rhododendron sp., with some accompanying species such as Spiraea alpina, Lonicera tibetica, Caragana tangutica, Festuca ovina, and Elymus nutans. The grass community usually has 2 layers, with a height of $50-90 \mathrm{~cm}$ for the highest shrubs and an overall cover of $60-80 \%$.

2.2. Plant Composition and Biomass. Plant community characteristics were determined from two systematically located transects $(500 \mathrm{~cm} \times 50 \mathrm{~cm})$ of ten continuous quadrates $(50 \mathrm{~cm} \times 50 \mathrm{~cm})$ in each site. Plant species were identified and recorded, and the total ground cover, species canopy cover, and height were determined from $0.25 \mathrm{~m}^{2}$ quadrates. The frequency of each plant species was calculated for each quadrate. In each site, vegetation was clipped off flush with the ground from ten $0.25 \mathrm{~m}^{2}$ quadrates, selected randomly. The harvested plants were separated into graminoids $\left(C_{3}\right.$ and $\mathrm{C}_{4}$ plants), sedges, legumes, forbs, and woody plants. We dried the samples at $65^{\circ} \mathrm{C}$ for $48 \mathrm{~h}$ and weighed the dried samples. Community aboveground biomass (CAB) was measured August 15-25 of each year, the time of peak aboveground standing crop at each site. Root biomass was measured by collecting soil samples from depths of $0-40 \mathrm{~cm}$ 
from six $0.25 \times 0.25 \mathrm{~m}^{2}$ quadrats, which were colocated with the aboveground biomass measurement quadrats. The soil cores $\left(0.25 \times 0.25 \mathrm{~m}^{2}\right)$ were cut into segments corresponding to sampling depths of $0-10 \mathrm{~cm}, 10-20 \mathrm{~cm}$, and $20-40 \mathrm{~cm}$. Roots were first washed and then oven-dried at $65^{\circ} \mathrm{C}$ for 72 hours before being weighed.

2.3. Division of Plants into Functional Groups. Lavorel et al. [28] suggests that plants should be divided into functional groups as (1) emergent groups, which had similar biological attributes; (2) strategies, which included species that have similar attributes that could be interpreted as adaptations to particular patterns of resource use; (3) functional types, which were groups of species with similar roles in ecosystem processes that respond in similar ways to multiple environmental factors; (4) specific, which are species that respond in similar ways to specific environmental factors. We classified our species into five functional groups: sedges, legumes, graminoids, woody plants, and forbs. Since the functional groups at our site were represented with different initial abundances, we used standardized across groups using changes in abundance. Species classifications were as follows: Sedges: Kobresia pygmaea, Kobresia humilis, Kobresia tibetica, Carex pachyrrhiza, Scirpus distigmaticus; Legumes:Trigonella ruthenica, Oxytropis ochrocephala, Oxytropis kansuensis, Gueldenstaedtia diversifolia, and Astragalus polycladus; Graminoids:Poa pratensis, Stipa aliena, Festuca ovina, Festuca rubra, Ptilagrostis dichotoma, Koeleria cristata, Elymus nutans, and Helictotrichon tibeticum; Woody plants:Potentilla fruticosa; Forbs:Gentiana straminea, Gentiana farreri, Gentiana squarrosa, Potentilla nivea, Thalictrum alpinum, Ranunculus pulchellus, Gentianopsis paludosa, Leontopodium nanum, Leontopodium hastioides, Anaphalis lacteal, Viola philippica, Lancea tibetica, Halerpestes ruthenica, Halerpestes tricuspis, Ligularia virgaurea, Saussurea stella, Saussurea katochaete, and Taraxacum mongolicum.

2.4. Soil Sampling. Ten soil cores ( $5 \mathrm{~cm}$ in diameter, $0-40 \mathrm{~cm}$ depth) were collected in a V-shaped pattern in the six $0.25 \times$ $0.25 \mathrm{~m}^{2}$ plots. Each core was split into $0-10 \mathrm{~cm}, 10-20 \mathrm{~cm}$, and $20-40 \mathrm{~cm}$ sections. Samples were aggregated by plot and depth in the field, cooled to $4^{\circ} \mathrm{C}$ returned to the laboratory and processed within 2 days. Samples were collected on August 20th in 2003, 2004, and 2005.

2.5. Laboratory Analyses. Soils were kept chilled at approximately $4^{\circ} \mathrm{C}$. Once in the laboratory, soils were passed through a $4-\mathrm{mm}$ mesh to homogenize the samples and to remove roots and large rocks. Another portion of each sample was air-dried, finely ground to $0.1 \mathrm{~mm}$, and used to measure total organic C (TOC), total $N$, total $P$, available $N$, and available $P$. The TOC was determined using a TOC analyzer (SSM-5000A Shimadzu). Soil moisture was measured gravimetrically at $105^{\circ} \mathrm{C}$ for $24 \mathrm{~h}$. Soil bulk density was measured by the annulated sword method. $\mathrm{pH}$ and the content of other nutrients were analyzed using standard methods described in the soil analysis manual [29].
Microbial biomass $\mathrm{C}$ (MBC) was determined by the fumigation-extraction (FE) method [30]. Three subsamples of moist soil (equivalent to $5.0 \mathrm{~g}$ dry soil) were extracted with $20 \mathrm{~mL} 0.5 \mathrm{M} \mathrm{K}_{2} \mathrm{SO}_{4}$. The samples were shaken for $30 \mathrm{~min}$, filtered and frozen at $-20^{\circ} \mathrm{C}$. Simultaneously, three other subsamples of soil (also equivalent to $5.0 \mathrm{~g}$ dry soil) were fumigated with ethanol-free chloroform for $24 \mathrm{~h}$ at $2^{\circ} \mathrm{C}$, extracted and then frozen. Biomass $C(B C)$ was calculated from $B_{\mathrm{C}}=2.22 E_{\mathrm{C}}$, where $E_{\mathrm{C}}$ is (C extracted from fumigated soil $)-(\mathrm{C}$ extracted from nonfumigated soil). Extracted carbon was determined by an automated TOC Analyzer (Shimadzu, TOC-5000A, Japan). The soil enzyme activities of urease, protease, alkaline phosphatase, and invertase were analyzed using methods described in the soil enzyme analysis manual [31].

2.6. Calculation and Statistical Analysis. We calculated the soil microbial quotient $\left(\mathrm{Q}_{\mathrm{mic}}\right)$ as the ratio of soil microbial biomass carbon $\left(\mathrm{C}_{\text {mic }}\right)$ to soil organic carbon $\left(\mathrm{C}_{\text {org }}\right)$. Tests for significant differences among community in soil resources, soil microbial biomass carbon, soil microbial quotient, and soil enzyme activities at different depths were conducted using analysis of variance (ANOVA) with Duncan's multiple range tests. Relationships between microbial biomass, soil enzyme activity, and plant aboveground biomass were evaluated using the Spearman correlation coefficient. We also used a Spearman correlation coefficient to determine the relationships between plant aboveground biomass and several factors, including plant species richness (or functional group number), the coverage of plant functional groups, soil organic carbon content, and total soil nitrogen content. Multilinearity stepwise regression and path analysis were used to compare community aboveground biomass with soil chemical properties and soil enzyme activities. SPSS 10.0 software (Putian Electron Technology) was used to conduct these analyses.

\section{Results}

3.1. Chemical Properties. For $C_{\text {org }}$, total $N$ and soil available $N$ content, a significantly $(P<.05)$ higher concentration was observed in the KTS communities compared to the other three communities for a depth of $0-40 \mathrm{~cm}$ over the course of three years (Table 1). No significant difference $(P>.05)$ between soil total $P$, soil available $P$, and $\mathrm{pH}$ value at $0-40 \mathrm{~cm}$ was found over the three years.

3.2. Microbial Biomass $C$. $C_{\text {mic }}$ and $Q_{\text {mic }}$ showed a significant $(P<.05)$ interaction between different communities and depths. In general, they declined significantly $(P<.05)$ with depth (Table 2). At depths of $0-10 \mathrm{~cm}, 10-20 \mathrm{~cm}$, and 20$40 \mathrm{~cm}$, the $C_{\text {mic }}$ values for KTS soil were higher than those for the other three communities. KTS community soil also showed the highest $C_{\text {mic }}$ content and soil organic carbon. In addition, the lowest $Q_{\text {mic }}$ was found in the KTS (Tables 1 and 2). Soil organic carbon and soil microbial biomass carbon were closely correlated (Spearman correlation 0.84 $(P<.01))$. 
TABLE 1: Chemical properties of soil samples collected in four alpine meadow plant communities (Mean \pm SD). Numbers in parentheses indicate standard deviation $(n=6)$. Data from different communities at same year followed by the same letters were not significantly different at 0.05 levels (Duncan's multiple range tests). $C_{\text {mic }}$ : Microbial biomass C, $Q_{\text {mic }}$ : Soil microbial quotient. Kobresia humilis meadow $=$ KHM; Kobresia pygmaea meadow = KPM; Kobresia tibetica swamp meadow = KTS; Potentilla fruticosa scrub $=$ PFS.

\begin{tabular}{|c|c|c|c|c|c|c|c|c|c|}
\hline Community & Year & $\begin{array}{c}\text { Soil layer } \\
(\mathrm{cm})\end{array}$ & $\begin{array}{l}\text { Soil organic C } \\
\left(\mathrm{g} \mathrm{C} \mathrm{kg}^{-1} \text { soil }\right)\end{array}$ & $\begin{array}{l}\text { Soil total } \mathrm{N} \\
\left(\mathrm{g} \mathrm{N} \mathrm{kg}^{-1} \text { soil }\right) \\
\end{array}$ & $\begin{array}{l}\text { Soil total P } \\
\left(\mathrm{g} \mathrm{P} \mathrm{kg}^{-1} \text { soil }\right)\end{array}$ & $\begin{array}{c}\text { Soil available N } \\
(\mathrm{mg} / \mathrm{kg})\end{array}$ & $\begin{array}{c}\text { Soil available P } \\
(\mathrm{mg} / \mathrm{kg})\end{array}$ & $\begin{array}{c}\text { Soil moisture } \\
(\%)\end{array}$ & $\mathrm{pH}$ value \\
\hline \multirow{3}{*}{ KHM } & 2003 & $0-40$ & $1.012 b(0.11)$ & $5.76 b(0.19)$ & $0.65 \mathrm{a}(0.02)$ & $31.60 \mathrm{~b}(0.57)$ & $9.95 a(0.67)$ & $41.62 \mathrm{~b}(0.08)$ & $8.04 \mathrm{a}(0.02)$ \\
\hline & 2004 & $0-40$ & $0.983 b(0.17)$ & $5.39 b(0.16)$ & $0.63 a(0.03)$ & $30.40 \mathrm{~b}(0.14)$ & $11.28 \mathrm{a}(0.51)$ & $39.32 \mathrm{~b}(0.11)$ & $8.02 \mathrm{a}(0.02)$ \\
\hline & 2005 & $0-40$ & $1.017 b(0.13)$ & $5.37 \mathrm{~b}(0.24)$ & $0.62 \mathrm{a}(0.05)$ & $29.65 b(0.86)$ & $11.22 \mathrm{a}(1.08)$ & $38.43 b(0.07)$ & $8.05 a(0.01)$ \\
\hline \multirow{3}{*}{$K P M$} & 2003 & $0-40$ & $1.051 b(0.61)$ & $6.03 b(0.24)$ & $0.64 \mathrm{a}(0.04)$ & $36.10 b(8.78)$ & $10.31 \mathrm{a}(1.12)$ & $36.27 \mathrm{c}(0.03)$ & $8.02 \mathrm{a}(0.03)$ \\
\hline & 2004 & $0-40$ & $1.086 b(0.81)$ & $5.68 \mathrm{~b}(0.24)$ & $0.63 a(0.04)$ & $35.86 b(2.35)$ & $11.13 a(1.22)$ & $34.26 \mathrm{c}(0.04)$ & $8.03 a(0.02)$ \\
\hline & 2005 & $0-40$ & $1.066 \mathrm{~b}(0.12)$ & $5.67 b(0.18)$ & $0.63 \mathrm{a}(0.05)$ & $37.39 b(2.34)$ & $10.06 a(2.02)$ & $35.19 c(0.04)$ & 7.97a (0.03) \\
\hline \multirow{3}{*}{ KTS } & 2003 & $0-40$ & $92.79 a(5.74)$ & $12.62 \mathrm{a}(0.34)$ & $0.65 a(0.02)$ & 81.60a (1.57) & $11.28 \mathrm{a}(1.05)$ & $77.76 a(0.04)$ & $7.40 \mathrm{a}(0.09)$ \\
\hline & 2004 & $0-40$ & $94.89 a(2.96)$ & $11.95 a(0.25)$ & $0.64 a(0.03)$ & $81.80 \mathrm{a}(2.12)$ & $12.83 a(1.22)$ & $74.83 a(0.05)$ & 7.31a (0.14) \\
\hline & 2005 & $0-40$ & $94.68 \mathrm{a}(3.10)$ & $11.75 \mathrm{a}(0.34)$ & $0.63 \mathrm{a}(0.05)$ & $79.25 \mathrm{a}(1.15)$ & $13.81 \mathrm{a}(1.95)$ & $75.16 \mathrm{a}(0.07)$ & 7.20a (0.12) \\
\hline \multirow{3}{*}{ PFS } & 2003 & $0-40$ & $0.685 \mathrm{~b}(0.05)$ & $5.04 \mathrm{~b}(0.33)$ & $0.62 \mathrm{a}(0.05)$ & $30.33 b(2.55)$ & $10.88 \mathrm{a}(0.94)$ & $43.22 b(0.07)$ & 7.14a (0.02) \\
\hline & 2004 & $0-40$ & $0.605 b(0.07)$ & $4.67 b(0.15)$ & $0.64 \mathrm{a}(0.04)$ & $32.46 \mathrm{~b}(2.45)$ & $11.58 \mathrm{a}(1.38)$ & $40.51 b(0.06)$ & $7.16 \mathrm{a}(0.02)$ \\
\hline & 2005 & $0-40$ & $0.691 \mathrm{~b}(0.07)$ & $4.66 \mathrm{~b}(0.18)$ & $0.65 a(0.06)$ & $32.12 \mathrm{~b}(2.38)$ & $10.82 \mathrm{a}(1.36)$ & $40.51 b(0.11)$ & $7.13 \mathrm{a}(0.03)$ \\
\hline
\end{tabular}

TABle 2: Microbial biomass C of soil samples in four alpine meadow plant communities (Mean \pm SD). Data in the table were mean values of 3 years. Numbers in parentheses indicate standard deviation $(n=6)$. Data from different communities followed by the same letters were not significantly different at 0.05 levels (capital letters indicate different soil layers within the same community while small letters indicate the same soil layer in different communities; Duncan's multiple range tests). $C_{\text {mic }}$ : Soil microbial biomass carbon; $Q_{\text {mic }}$ : Soil microbial quotient. Kobresia humilis meadow $=$ KHM; Kobresia pygmaea meadow $=$ KPM; Kobresia tibetica swamp meadow $=$ KTS; Potentilla fruticosa scrub = PFS.

\begin{tabular}{|c|c|c|c|c|c|c|c|c|}
\hline \multirow{3}{*}{ Community } & \multicolumn{4}{|c|}{$C_{\text {mic }}\left(\mathrm{g} \mathrm{C} \mathrm{kg}^{-1}\right.$ soil $)$} & \multicolumn{4}{|c|}{$Q_{\text {mic }}$} \\
\hline & Depth $(\mathrm{cm})$ & & & & Depth $(\mathrm{cm})$ & & & \\
\hline & $0-10$ & $10-20$ & $20-40$ & $0-40$ & $0-10$ & $10-20$ & $20-40$ & $0-40$ \\
\hline KHM & $\begin{array}{c}0.58 \mathrm{~A} \mathrm{~b} \\
(0.01)\end{array}$ & $\begin{array}{c}0.28 \mathrm{~B} \mathrm{~b} \\
(0.01)\end{array}$ & $\begin{array}{c}0.19 \mathrm{C} \mathrm{b} \\
(0.01)\end{array}$ & $0.35 \mathrm{~b}(0.01)$ & $\begin{array}{c}0.41 \mathrm{~A} \mathrm{a} \\
(0.13)\end{array}$ & $\begin{array}{c}0.33 \mathrm{~B} a \\
(0.15)\end{array}$ & $\begin{array}{c}0.29 \mathrm{C} \mathrm{a} \\
(0.04)\end{array}$ & $0.36 \mathrm{a}(0.09)$ \\
\hline$K P M$ & $\begin{array}{c}0.52 \mathrm{~A} \mathrm{~b} \\
(0.03)\end{array}$ & $\begin{array}{c}0.29 \mathrm{~B} \mathrm{~b} \\
(0.02)\end{array}$ & $\begin{array}{c}0.18 \mathrm{Cb} \\
(0.01)\end{array}$ & $0.33 \mathrm{~b}(0.02)$ & $\begin{array}{c}0.33 \mathrm{~A} \mathrm{a} \\
(0.07)\end{array}$ & $\begin{array}{c}0.28 \mathrm{~B} \mathrm{a} \\
(0.07)\end{array}$ & $\begin{array}{c}0.25 \mathrm{~B} \mathrm{a} \\
(0.05)\end{array}$ & $0.30 \mathrm{a}(0.06)$ \\
\hline KTS & $\begin{array}{c}2.99 \mathrm{~A} \mathrm{a} \\
(0.36)\end{array}$ & $\begin{array}{c}1.78 \mathrm{~B} \mathrm{a} \\
(0.26)\end{array}$ & $\begin{array}{c}0.38 \mathrm{C} \mathrm{a} \\
(0.12)\end{array}$ & $1.72 \mathrm{a}(0.24)$ & $\begin{array}{c}0.023 \mathrm{~A} \mathrm{~b} \\
(0.003)\end{array}$ & $\begin{array}{c}0.018 \mathrm{Bb} \\
(0.005)\end{array}$ & $\begin{array}{c}0.016 \mathrm{~B} \mathrm{~b} \\
(0.002)\end{array}$ & $0.018 \mathrm{~b}(0.002)$ \\
\hline PFS & $\begin{array}{c}0.31 \mathrm{~A} \mathrm{c} \\
(0.01)\end{array}$ & $\begin{array}{c}0.21 \mathrm{~B} \mathrm{~b} \\
(0.02)\end{array}$ & $\begin{array}{c}0.12 \mathrm{Cb} \\
(0.02)\end{array}$ & $0.21 \mathrm{~b}(0.02)$ & $\begin{array}{c}0.39 \mathrm{~A} \mathrm{a} \\
(0.05)\end{array}$ & $\begin{array}{c}0.31 \mathrm{~B} \mathrm{a} \\
(0.06)\end{array}$ & $\begin{array}{c}0.22 \mathrm{C} \mathrm{a} \\
(0.05)\end{array}$ & $0.32 \mathrm{a}(0.04)$ \\
\hline
\end{tabular}

3.3. Soil Enzyme Activities. Significant differences $(P<.05)$ among communities and depths were found for all enzyme activities (Figure 1). The highest enzyme activities were found at $0-10 \mathrm{~cm}$ depth $(P<.05)$, and the lowest enzyme activities were found at $20-40 \mathrm{~cm}$ depth $(P<.05)$. The highest urease and invertase activities in KTS were seen at $0-10 \mathrm{~cm}$ depth $(F=216.59, P=.0001 ; F=86.92$, $P=.001)$. The highest protease activities in KPM were found at $0-10 \mathrm{~cm}$ depth $(F=522.02, P=.0001)$. Urease activity was significantly correlated with soil organic $C$ and soil microbial biomass C (Spearman correlation 0.79 and $0.80(P<.05)$, resp. $)$, whereas protease activity was not significantly correlated with either soil organic $C$ or soil microbial biomass C. Alkali phosphatase activity was higher in soils from the PFS community than in the other three soils for all depths. This difference was significant for $0-10 \mathrm{~cm}$ and $10-20 \mathrm{~cm}$ depths $(P<.05)$, but not for $20-40 \mathrm{~cm}$ depth. The highest activity was found at $0-10 \mathrm{~cm}$ in the PFS community.
3.4. Plant Functional Group Composition and Aboveground Biomass. Aboveground biomass is used here as an estimate of plant community production. In the KTS community, the aboveground biomass was composed mostly of plants from the dominant sedge species, $K$. tibetica $(\approx 85 \%$ of aboveground biomass). In the KPM and KHM communities, the aboveground biomass was composed of a mixture of forbs, graminoids, legumes, and sedges. Forbs comprised about $39 \%$ of the aboveground biomass in the KPM community and $26 \%$ of the aboveground biomass in the KHM community. Grass $\left(\mathrm{C}_{3}\right.$ and $\mathrm{C}_{4}$ grasses $)$ comprised about $26 \%$ of the aboveground biomass in the KPM community and $42 \%$ of the aboveground biomass in the KHM community. Legumes comprised about $18 \%$ of the aboveground biomass in the KHM community and $14 \%$ in the KPM community. In the PFS community, the aboveground biomass was composed of a mixture of graminoids $\left(\mathrm{C}_{3}\right.$ and $\mathrm{C}_{4}$ grasses $)$, forbs, and woody plants. Graminoids, forbs and woody plants 


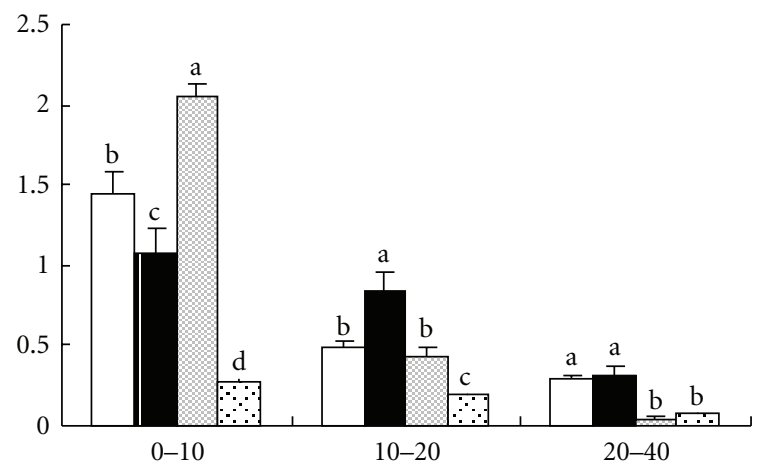

(a)

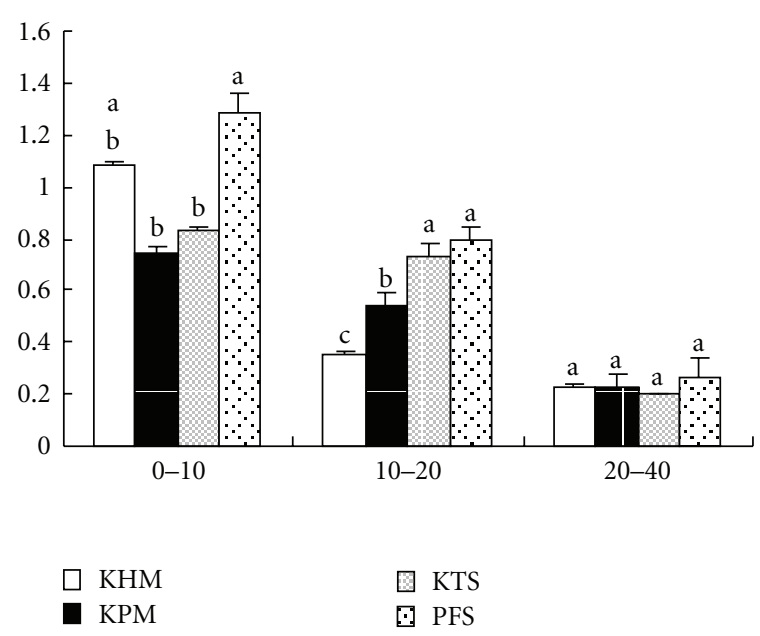

(c)

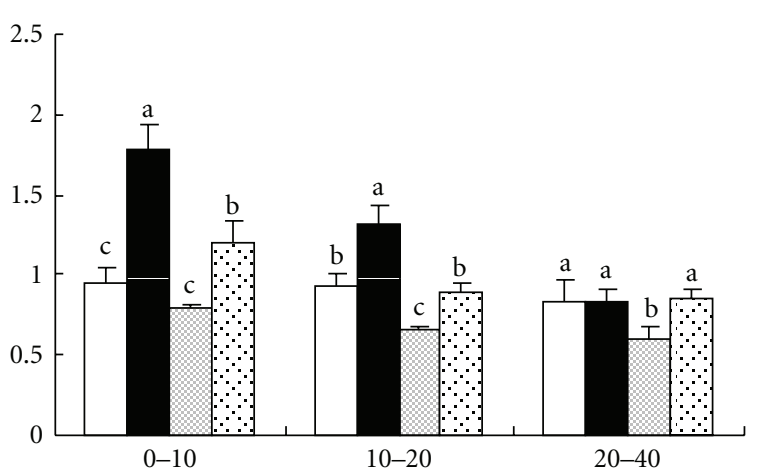

(b)

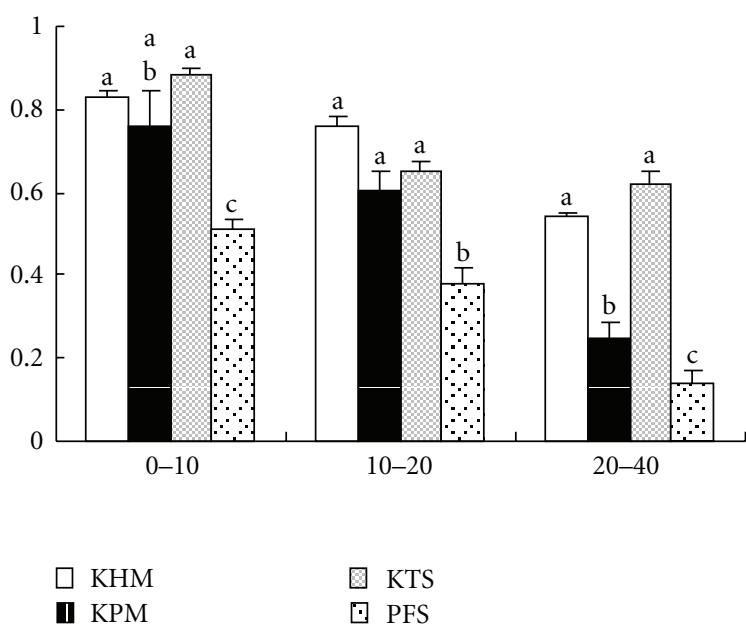

(d)

FIGURE 1: Soil enzyme activities (per gram dry weight) from samples collected at different depths in the four meadow communities: (a) urease ( $\mathrm{mg} \mathrm{NH}_{4}-\mathrm{N} / \mathrm{g}$ ); (B) protease (mg Tyr/g); (c) alkali phosphatase (mg phenol/g); (d) invertase (mg glucose/g). Bars indicate standard deviation $(n=6)$. At the same depth for different communities, values with the same letters are not significantly different $(P \leq .05)$. Kobresia humilis meadow $=$ KHM; Kobresia pygmaea meadow $=$ KPM; Kobresia tibetica swamp meadow $=$ KTS; Potentilla fruticosa scrub $=$ PFS .

comprised about $37 \%, 25 \%$ and $18 \%$ of the aboveground biomass in the PFS community, respectively (Figure 2).

\subsection{Correlation Plant Functional Groups and Aboveground} Biomass. Further correlation analysis (Table 3 ) showed that, in the KHM and PFS communities, the community aboveground biomass had a significant positive correlation $(P<$ $.05)$ with the aboveground biomass of the legume group. In the KTS community, aboveground biomass had a significant positive correlation $(P<.05)$ with the aboveground biomass of the sedge group. There is a negative correlation between $\mathrm{C}_{3}$ grass aboveground biomass and sedge aboveground biomass, and a positive correlation between legume aboveground biomass and sedge aboveground biomass in KHM, KPM, and PFS communities, but not up to significantly level $(P>.05)$.

3.6. Functional Composition and Diversity in Response to Soil Nutrients. In the KTS community, CAB was negatively correlated with the number of plant species $\left(r_{\mathrm{s}}=-0.900, P=\right.$ .037). Coverage of forbs, sedges, and grasses showed a linear relationship with their respective aboveground biomass of the functional group $\left(r_{s}=0.900, P=.037 ; r_{s}=0.999\right.$,
$\left.P=.0001 ; r_{s}=0.894, P=.041\right)$. CAB was positively correlated with soil organic carbon $\left(r_{s}=0.982, P=.003\right)$. In the KPM community, the coverage of sedges, grasses, and legumes had a significant linear relationship with their respective aboveground biomass of the functional group $\left(r_{s}=0.999, P=.0001 ; r_{s}=0.999, P=.0001 ; r_{s}=0.975, P=\right.$ $.005)$, and $\mathrm{CAB}$ was positively correlated with soil organic carbon $\left(r_{s}=0.999, P=.0001\right)$ and soil total nitrogen $\left(r_{s}=0.975, P=.005\right)$. In the KHM community, the coverage of forbs, sedges, grasses, and legumes had a significant linear relationship with their respective aboveground biomass of the functional group $\left(r_{s}=0.999, P=.0001 ; r_{s}=0.900\right.$, $\left.P=.037 ; r_{s}=0.898, P=.038 ; r_{s}=0.975, P=.005\right)$, and $\mathrm{CAB}$ was positively correlated to soil organic carbon $\left(r_{s}=0.894, P=.040\right)$ and soil total nitrogen $\left(r_{s}=0.900, P=\right.$ .037). In the PFS community, the coverage of forbs, sedges, grasses, legumes, and woody plants had a significant linear relationship with their respective aboveground biomass of the functional group $\left(r_{s}=0.999, P=.0001 ; r_{s}=0.998\right.$, $P=.0001 ; r_{s}=0.894, P=.041 ; r_{s}=0.999, P=$ $\left..0001 ; r_{s}=0.975, P=.005\right)$, and $\mathrm{CAB}$ was positively correlated to soil organic carbon $\left(r_{s}=0.921, P=.026\right)$ 


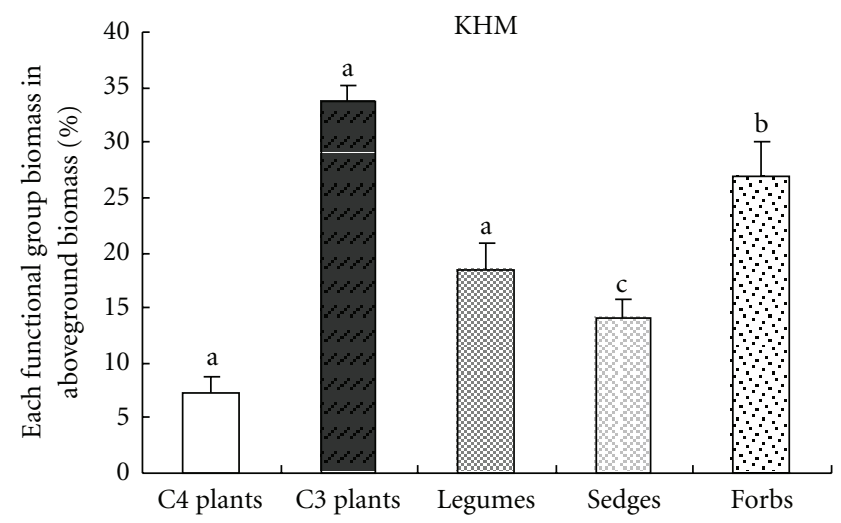

(a)

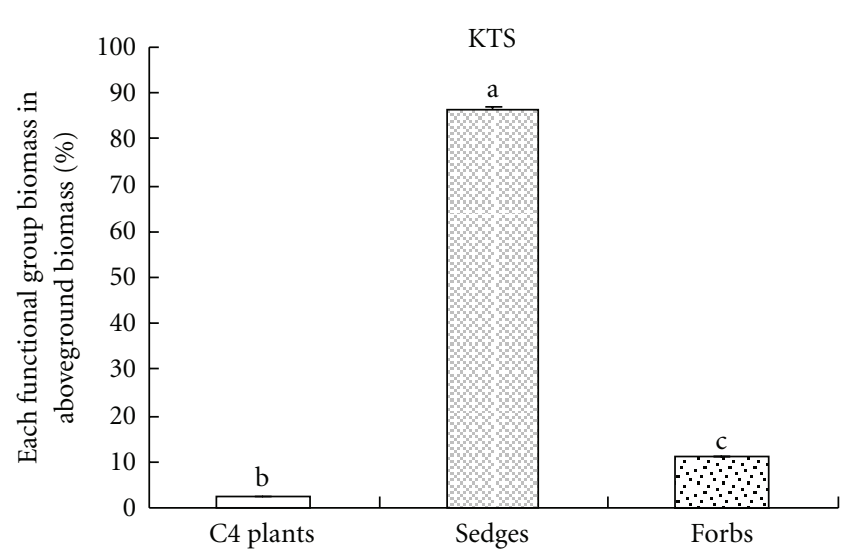

(c)

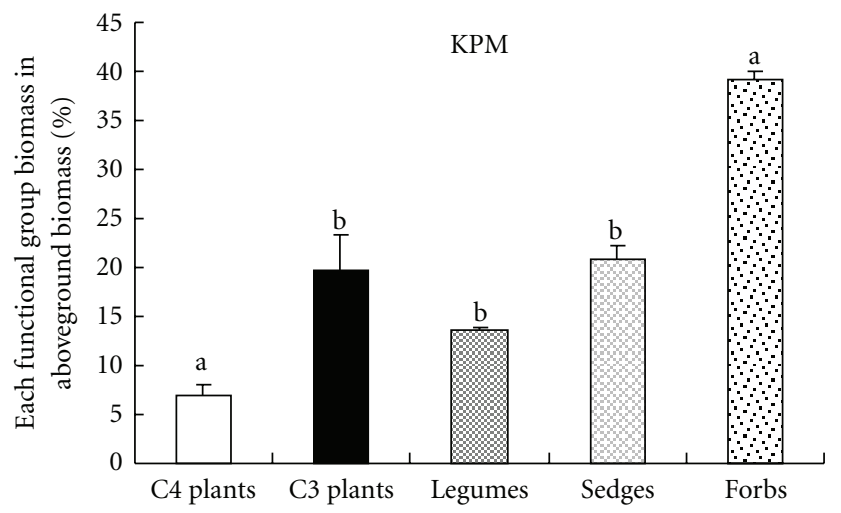

(b)

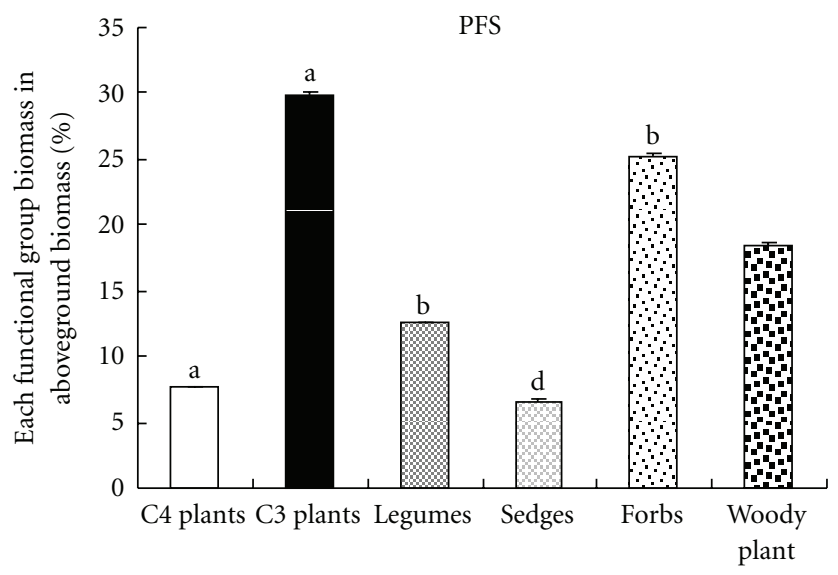

(d)

FIgURE 2: Distribution of biomass (Mean $\pm \mathrm{SD}, n=10, \mathrm{~g} / \mathrm{m}^{2}$ ) in the KHM, KPM, KTS, and PFS communities. The percent of each functional group in the total aboveground biomass is indicated above the $X$-axis. At the same functional group biomass percent for different community, values with the same letters are not significantly different $(P \leq .05)$ (one-way ANOVA analyses for forbs, $C_{4}$ plants, $C_{3}$ plants, sedges, and legumes). Kobresia humilis meadow = KHM; Kobresia pygmaea meadow = KPM; Kobresia tibetica swamp meadow = KTS; Potentilla fruticosa scrub $=$ PFS.

TABLE 3: Correlation coefficients between plant functional groups and aboveground biomass. Spearman's rank correlation coefficients $(n=$ 10). L: Legumes; CAB: Community aboveground biomass; $S$, Sedges; $\mathrm{C}_{3}$ : Grasses with the three-carbon photosynthetic pathway $\left(\mathrm{C}_{3}\right)$; W: Woody plants; Kobresia humilis meadow $=$ KHM; Kobresia pygmaea meadow $=$ KPM; Kobresia tibetica swamp meadow $=$ KTS; Potentilla fruticosa scrub $=$ PFS.

\begin{tabular}{|c|c|c|c|c|c|c|c|}
\hline \multirow{2}{*}{ Community } & \multirow{2}{*}{$\begin{array}{l}\text { Plant functional } \\
\text { groups }\end{array}$} & \multirow{2}{*}{$\begin{array}{c}2003 \\
\text { Correlation } \\
\text { coefficient }(r)\end{array}$} & \multirow[b]{2}{*}{$P$} & \multicolumn{2}{|l|}{2004} & \multicolumn{2}{|l|}{2005} \\
\hline & & & & $\begin{array}{c}\text { Correlation } \\
\text { coefficient }(r)\end{array}$ & $P$ & $\begin{array}{c}\text { Correlation } \\
\text { coefficient }(r)\end{array}$ & $P$ \\
\hline \multirow{3}{*}{ KHM } & L versus $\mathrm{CAB}$ & 0.900 & .037 & 0.866 & .029 & 0.900 & .037 \\
\hline & L versus S & 0.600 & .285 & 0.400 & .505 & 0.500 & .391 \\
\hline & $\mathrm{C}_{3}$ versus $\mathrm{S}$ & -0.300 & .624 & -0.300 & .624 & -0.707 & .188 \\
\hline \multirow{3}{*}{$K P M$} & L versus $\mathrm{CAB}$ & 0.200 & .747 & 0.800 & .104 & 0.300 & .624 \\
\hline & L versus S & 0.500 & .391 & 0.400 & .505 & 0.900 & .037 \\
\hline & $\mathrm{C}_{3}$ versus $\mathrm{S}$ & -0.400 & .624 & -0.400 & .505 & -0.300 & .624 \\
\hline KTS & $S$ versus $\mathrm{CAB}$ & 0.988 & .002 & 0.982 & .003 & 0.971 & .006 \\
\hline \multirow{4}{*}{ PFS } & $\mathrm{L}$ versus $\mathrm{CAB}$ & 0.866 & .029 & 0.898 & .038 & 0.901 & .037 \\
\hline & W versus $C A B$ & 0.540 & .348 & 0.699 & .189 & 0.818 & .138 \\
\hline & L versus S & 0.757 & .139 & 0.388 & .518 & 0.350 & .564 \\
\hline & $\mathrm{C}_{3}$ versus $\mathrm{S}$ & -0.457 & .439 & -0.558 & .328 & -0.534 & .354 \\
\hline
\end{tabular}


TABLE 4: Path analysis on CAB to soil C and soil enzyme activity.

\begin{tabular}{|c|c|c|c|c|c|c|c|c|c|}
\hline \multirow[t]{2}{*}{ Vegetation type } & \multirow[t]{2}{*}{ Factors } & \multirow[t]{2}{*}{$\begin{array}{c}\text { Decision } \\
\text { coefficient }\end{array}$} & \multirow[t]{2}{*}{$\begin{array}{l}\text { Direct path } \\
\text { coefficient }\end{array}$} & \multicolumn{5}{|c|}{ Indirect path coefficient } & \multirow[t]{2}{*}{$\begin{array}{c}\text { Residual path } \\
\text { coefficient }\end{array}$} \\
\hline & & & & Sum & $\mathrm{X}_{1}$ & $\mathrm{X}_{3}$ & $\mathrm{X}_{5}$ & $\mathrm{X}_{6}$ & \\
\hline \multirow{4}{*}{ K. humilis meadow } & $\mathrm{X}_{1}$ & \multirow{4}{*}{0.9980} & 0.5514 & -1.0813 & & -0.1062 & -0.9303 & -0.0448 & \multirow{4}{*}{0.0447} \\
\hline & $\mathrm{X}_{3}$ & & 0.9041 & -0.8618 & -0.0648 & & -0.1141 & -0.6829 & \\
\hline & $\mathrm{X}_{5}$ & & 1.442 & -0.4759 & -0.3557 & -0.0716 & & -0.0486 & \\
\hline & $\mathrm{X}_{6}$ & & -0.7558 & 0.9424 & 0.0327 & 0.8169 & 0.0928 & & \\
\hline \multirow{5}{*}{ K. pygmaea meadow } & & \multirow{5}{*}{0.9982} & & Sum & $\mathrm{X}_{1}$ & $\mathrm{X}_{2}$ & $\mathrm{X}_{4}$ & $\mathrm{X}_{6}$ & \multirow{5}{*}{0.0425} \\
\hline & $\mathrm{X}_{1}$ & & -0.1287 & -0.3535 & & -0.5273 & 0.3074 & -0.1336 & \\
\hline & $\mathrm{X}_{2}$ & & 1.6879 & -0.8951 & 0.0402 & & -0.7847 & -0.1506 & \\
\hline & $\mathrm{X}_{4}$ & & 1.3326 & -1.8235 & -0.0297 & -0.9939 & & -0.7999 & \\
\hline & $\mathrm{X}_{6}$ & & -1.247 & 1.0449 & -0.0138 & 0.2039 & 0.8548 & & \\
\hline \multirow{5}{*}{$\begin{array}{l}\text { K. tibetica swamp } \\
\text { meadow }\end{array}$} & & \multirow{5}{*}{0.9968} & & Sum & $\mathrm{X}_{1}$ & $\mathrm{X}_{3}$ & $\mathrm{X}_{4}$ & $\mathrm{X}_{5}$ & \multirow{5}{*}{0.0567} \\
\hline & $\mathrm{X}_{1}$ & & 0.8422 & 0.1142 & & -0.0049 & -0.2185 & 0.3376 & \\
\hline & $\mathrm{X}_{3}$ & & -0.7938 & 0.2236 & 0.2302 & & -0.1331 & 0.1265 & \\
\hline & $\mathrm{X}_{4}$ & & 0.5463 & 0.3561 & -0.0869 & 0.169 & & 0.274 & \\
\hline & $\mathrm{X}_{5}$ & & -0.4195 & -0.0984 & 0.0493 & 0.2092 & -0.3569 & & \\
\hline \multirow{5}{*}{$\begin{array}{l}\text { Potentilla fruticosa } \\
\text { shrub meadow }\end{array}$} & & \multirow{5}{*}{0.9906} & & Sum & $\mathrm{X}_{1}$ & $\mathrm{X}_{2}$ & $\mathrm{X}_{3}$ & $\mathrm{X}_{5}$ & \multirow{5}{*}{0.0890} \\
\hline & $\mathrm{X}_{1}$ & & 1.6654 & -2.1592 & & -0.8184 & 0.1685 & -1.5093 & \\
\hline & $\mathrm{X}_{2}$ & & -1.2846 & 0.4194 & 1.0564 & & 0.6073 & -1.2443 & \\
\hline & $\mathrm{X}_{3}$ & & -1.2521 & 1.8134 & -0.2241 & 0.6231 & & 1.4144 & \\
\hline & $\mathrm{X}_{5}$ & & 2.021 & -1.3292 & -1.2438 & 0.7909 & -0.8763 & & \\
\hline
\end{tabular}

$\mathrm{Y}$ : $\mathrm{CAB}, \mathrm{X}_{1}$ : Soil organic carbon, $\mathrm{X}_{2}$ : Soil microbial biomass $\mathrm{C}, \mathrm{X}_{3}$ : Urease, $\mathrm{X}_{4}$ : Protease, $\mathrm{X}_{5}$ : Alkali phosphatase, $\mathrm{X}_{6}$ : Invertase.

and soil total nitrogen $\left(r_{s}=0.868, P=.049\right)$. The number of functional groups (NF) had no correlation with $\mathrm{CAB}$ in the four alpine meadow communities. The number of species per functional group $(\mathrm{S} / \mathrm{F})$ was also not correlated with functional group aboveground biomass (FAB) in the four alpine meadow communities. Meanwhile, $\mathrm{CAB}$ was not significantly correlated to the number of plant species in the KHM, KPM, and PFS communities.

3.7. Effects of Soil Carbon and Enzyme Activity on CAB. In natural grassland, community biomasses depend on not only vegetation structure and function; and they reflect soil characteristics and sustainable supplied ability of soil resources. Path analysis was used to explain the effects of soil organic $\mathrm{C}$, microbial biomass $\mathrm{C}$, and enzyme activity on CAB. In KHM community, CAB was mainly influenced by urease, alkali phosphatase, and soil organic $C$, urease, alkali phosphatase of direct effect >soil organic C. Meanwhile, invertase indirectly affected CAB. The results showed that urease, alkali phosphatase, and soil organic $\mathrm{C}$ are key factor; invertase are secondly to influence CAB (Table 4). CAB was influenced by soil microbial biomass $\mathrm{C}$ and protease and was positively affected; invertase and soil organic $\mathrm{C}$ indicated indirect effect for $\mathrm{CAB}$ and all through soil microbial biomass $\mathrm{C}$ to control $\mathrm{CAB}$ in KPM community (Table 4). In the KTS community, $\mathrm{CAB}$ was influenced by soil organic $\mathrm{C}$ and protease and was positively affected; soil organic $C$ and protease through alkali phosphatase, urease and alkali phosphatase to afford CAB. Soil organic C, protease, urease, and alkali phosphatase all have direct or indirect effect on CAB through soil organic $\mathrm{C}$ (Table 4 ). Soil organic $\mathrm{C}$ and alkali phosphatase have positive effect for $\mathrm{CAB}$; soil microbial biomass $\mathrm{C}$ and urease have negative effect on $\mathrm{CAB}$; soil organic $C$, soil microbial biomass $C$, and urease all have direct or indirect effect on $\mathrm{CAB}$ through alkali phosphatase in the PFS community (Table 4).

\section{Discussion}

4.1. Microbial Biomass $C$. $C_{\mathrm{mic}}$ is more sensitive than total organic $\mathrm{C}$ for indicating soil changes, because it is related to soil microorganisms that are sensitive to soil variations [32]. According to earlier findings [33], the values of $C_{\text {mic }}$ and $C_{\text {org }}$ decrease with soil depth. These results are consistent with our findings. In this study, the values of $C_{\text {mic }}$ and $C_{\text {org }}$ in the KTS community are significantly higher than in the other alpine meadows. The differences in microbial biomass in the KTS community relative to other alpine meadows may be attributed to higher levels of organic compounds (i.e., detritus) that are likely to have resulted in a greater $C_{\text {mic }}$ level. The ratio of $C_{\text {mic }} / C_{\text {org }}$ in the KTS community is obviously lower than in the other alpine meadows.

4.2. Soil Enzyme Activities. The mineralization of soil organic matter is catalyzed by soil enzymes produced largely by microbes in the soil, although some enzymes are produced by certain plants [34]. Higher urease activity was found in KTS soil than in the other three meadow soils. This 
finding suggests that urease activity may be affected not only by soil resources, such as soil organic carbon, soil total nitrogen, and soil available nitrogen supply, but also by community aboveground biomass in all the four examined meadows. Urease activity decreases with soil depth in every alpine meadow soil, which can be attributed to the lack of specific substrates in these layers and to the low content of microbial biomass carbon and total organic carbon. No obvious regulation was found for alkali phosphatase in our results. This finding suggests that soil total phosphorus and soil available phosphorus directly or indirectly restrict the activity of alkali phosphatase. Hydrolysis of $\beta$-glucosides in soil or in decomposing plant residues [35] is an important reaction for making degradable substrates available to soil microorganisms [36]. Rodriguez-Loinaza et al. [37] found positive correlations between organic matter content and $\beta$-glucosidase, acid, and alkaline phosphatase and urease. Many previous studies have described positive correlations between $\beta$-glucosidase, arylsulphatase, phosphatase, amidase, urease, and other soil enzymes, with organic C $[38,39]$. Activation of invertase by high herbaceous biomass indicates enhanced hydrolysis of the $\mathrm{C}$ that is derived from the plant community biomass and from plant litter. Higher plant productivity presumably resulted in higher amounts of organic C entering the soil system, which may have led to higher soil enzyme activity. Plants and soil microorganisms are generally considered to be dependent on each other. On the one hand, plants provide C substrates for soil microorganisms. On the other hand, plants depend on microorganisms to obtain available soil nutrients.

\subsection{Functional Composition and Diversity in Response to Soil} Nutrients. Regional temperature and rainfall gradients, soils and land use determine the species composition and distribution of different grassland types [40]. Tilman et al. [41, 42] found a positive correlation between species diversity and productivity, especially for aboveground biomass. In our data, the highest CAB occurred in the sedge-dominated KTS community, and the lowest $\mathrm{CAB}$ was observed in the more diverse PFS communities, which are dominated by a mixture of graminoids, forbs, and woody plants. The proportion of each functional group within the total community biomass was indicative of community differences in species composition and functional group composition. In the present study, a significant correlation was found between coverage per functional group and aboveground biomass of functional groups in the four alpine meadows. The area a functional group covers can directly reflect the area that functional group has to assimilate nutrients: higher coverage by the functional group indicates greater access to soil nutrients and greater aboveground biomass produced. Wang et al., [43] obtained similar results, with a significant correlation between coverage per functional group and primary productivity of communities in these four types of alpine meadows. Soil organic matter content, and available $\mathrm{N}$ and $\mathrm{P}$, were negatively and closely related to plant diversity (species richness, Shannon-Wiener diversity index, and Pielou evenness index) [44].
Morse et al. [45] suggest that species diversity changes with variation in resource distribution in a manner that depends on organism size and habitat requirements. Significant correlations of plant biomass with soil resources (e.g., soil organic carbon and total soil nitrogen) suggest that fluctuations in soil resources (near the soil surface) affect plant biomass distribution [46]. Different species may have different rooting depths [47], may vary in their ability to exploit high nutrient patches [48], or may differ in their relative uptake rates of different types of $N$ [49]. We found that the KHM, KPM, and PFS communities are controlled by multidominant plant species. The KTS communities are mainly dominated by $K$. tibetica, forming a plant community controlled by single-dominant plant species. In this community, competition may play a greater role in determining species (or functional) composition and vegetation structure [43].

Interspecific (or interfunctional) competition may exert "selective pressure" whenever a species or plant functional group is associated with a resource for which its use is dominated by another species or plant functional group. Thus, in the KTS community, with its high intrinsic soil moisture content, excessive water may have led to a decrease in the spatial heterogeneity of nutrient resources and increased competition between plant species (or functional groups), resulting in the reduction of species and functional group diversity observed and dominance in productivity by the few remaining functional groups. In addition, in the more resource-rich KTS community, the dominant functional group (sedges) might have increased their abundance following higher levels of soil fertility, whereas subordinate forbs of low stature should decrease in abundance due to competition for light. In the resource-poor KHM, KPM, and $P F S$ communities, each functional group should be more responsive to soil nutrients and increase their respective abundance following the lower levels of soil fertility. These responses to soil resource levels should result in an increase in functional diversity (or plant diversity) in the KHM, KPM and PFS communities, because subordinate forbs of low stature would be released from nutrient limitation. In the KTS community, increased soil fertility would decrease functional group diversity (plant diversity). The distribution of above- and belowground biomass is largely influenced by plant species and growth forms within spatial gradients in soil moisture and edaphic conditions [46]. Species traits (such as the ability to respond to higher nutrient levels) as well as their competitive interactions may determine ecosystem functions, such as productivity. Plants with higher competitive abilities would then have access to a greater proportion of available resources, leading to increased total resource uptake by roots, lower nutrient losses from the ecosystem, and increased aboveground and belowground biomass.

4.4. Effects of Microbial Biomass and Enzyme Activity on CAB. Soil nutrients exist in a variety of inorganic (e.g., ammonium, phosphate) and organic (e.g., amino acids, nucleic acids) pools made available to plants through the action of soil enzymes (e.g., proteases, ribonucleases), the bulk of 
which are thought to come from bacteria and fungi [50]. One essential microbial function in soils is the processing and recovery of key nutrients from detrital inputs and accumulated soil organic matter [51]. The carbon resources that support soil microbial communities are primarily derived from plants, so it is likely that the soil microbial community should respond to changes in plant diversity or productivity, particularly if the plant community affects the quality or quantity of available carbon [52]. In this study, we find that variation in plant diversity and composition of plant communities is associated with levels of soil carbon and plant biomass. The higher levels of $C_{\text {mic }}$ and $C_{\text {org }}$ were observed in the KTS community. In the KTS, CAB was negatively correlated to species richness $\left(r_{\mathrm{s}}=-0.900, P=.037\right)$, was positively correlated to soil organic matter $\left(r_{\mathrm{s}}=0.982, P=\right.$ $.003)$ and soil moisture $\left(r_{\mathrm{s}}=0.921, P=.026\right)$. However, CAB in the KHM, KPM, and PFS communities was positively correlated to soil organic matter and soil total nitrogen $(P<$ $.05)$. Moreover, the results of path analysis showed that CAB is not only directly or indirectly influenced by soil organic $\mathrm{C}$ and soil microbial biomass $\mathrm{C}$, but also is directly or indirectly affected by the soil enzyme activities (urease, protease, alkali phosphatase, and invertase). Wang et al. [44]suggested that significant negative correlations were found between species richness and soil organic matter, soil available $\mathrm{N}$ and soil available $P$; similar results were obtained when ShannonWiener and Pielou indices were compared with soil available $P$; it is possible that the soil resources could determine species richness indirectly.

The manipulation of nitrogen enrichment and litter in the KHM could increase total organic $\mathrm{C}$ and soil microbial biomass, which in turn, increased the activities of soil urease, protease, alkali phosphatase, and invertase. But fertilization and litter removal treatments had no significant effect on the living plant biomass, microbial biomass, enzyme activity, or plant litter biomass in the KTS community. The results suggest that the original soil conditions, plant community composition, and community productivity are more important regulators of plant community productivity, and microbial biomass and activity than fertilization and litter biomass in swamp meadows [25]. Soil enzyme activities have been related to soil physio-chemical characters and plant primary production to change in vegetation.

\section{Acknowledgments}

The authors thank colleagues that helped with fieldwork over the study years. They also gratefully thank referees who provided helpful comments on earlier versions of the paper. This study was funded by the postgraduate's degree construction project (2011XWD-S071012) of the Southwest University for Nationalities, the National Key Scientific Program (973) (no. 2007CB411504) and the Program Introducing Talents of Discipline to Southwest University for Nationalities.

\section{References}

[1] B. H. Walker, "Biodiversity and ecological redundancy," Conservation Biology, vol. 6, no. 1, pp. 18-23, 1992.
[2] T. J. Givnish, “Does diversity beget stability?” Nature, vol. 371, pp. 113-114, 1994.

[3] D. Tilman, D. Wedin, and J. Knops, "Productivity and sustainability influenced by biodiversity in grassland ecosystems," Nature, vol. 379, pp. 718-720, 1996.

[4] D. Tilman, Plant Strategies and the Dynamics and Structure of Plant Communities, Princeton University, Princeton, NJ, USA, 1988.

[5] P. B. Reich, J. Knops, D. Tilman et al., "Plant diversity enhances ecosystem responses to elevated $\mathrm{CO}_{2}$ and nitrogen deposition," Nature, vol. 410, no. 6830, pp. 809-812, 2001.

[6] P. B. Reich, D. Tilman, S. Naeem et al., "Species and functional group diversity independently influence biomass accumulation and its response to $\mathrm{CO}_{2}$ and N," Proceedings of the National Academy of Sciences of the United States of America, vol. 101, no. 27, pp. 10101-10106, 2004.

[7] J. G. Ehrenfeld, B. Ravit, and K. Elgersma, "Feedback in the plant-soil system," Annual Review of Environment and Resources, vol. 30, pp. 75-115, 2005.

[8] D. R. Zak, W. E. Holmes, D. C. White, A. D. Peacock, and D. Tilman, "Plant diversity, soil microbial communities, and ecosystem function: are there any links?" Ecology, vol. 84, no. 8, pp. 2042-2050, 2003.

[9] H. L. Reynolds, A. Packer, J. D. Bever, and K. Clay, "Grassroots ecology: plant-microbe-soil interactions as drivers of plant community structure and dynamics," Ecology, vol. 84, no. 9, pp. 2281-2291, 2003.

[10] D. Tilman, "Secondary succession and the pattern of plant dominance along experimental nitrogen gradients," Ecological Monographs, vol. 57, no. 3, pp. 189-214, 1987.

[11] J. L. Smith and E. A. Paul, "The significance of soil microbial biomass estimations," in Soil Biochemistry, J. Bollag and G. Stotsky, Eds., pp. 357-396, Marcel Dekker, New York, NY, USA, 1990.

[12] V. Acosta-Martínez, L. Cruz, D. Sotomayor-Ramírez, and L. Pérez-Alegría, "Enzyme activities as affected by soil properties and land use in a tropical watershed," Applied Soil Ecology, vol. 35, no. 1, pp. 35-45, 2007.

[13] D. W. Bergstrom, C. M. Monreal, and D. J. King, "Sensitivity of soil enzyme activities to conservation practices," Soil Science Society of America Journal, vol. 62, no. 5, pp. 1286-1295, 1998.

[14] J. A. Amador, A. M. Glucksman, J. B. Lyons, and J. H. Görres, "Spatial distribution of soil phosphatase activity within a riparian forest," Soil Science, vol. 162, no. 11, pp. 808-825, 1997.

[15] M. P. Waldrop, T. C. Balser, and M. K. Firestone, "Linking microbial community composition to function in a tropical soil," Soil Biology and Biochemistry, vol. 32, no. 13, pp. 18371846, 2000.

[16] P. S. Kourtev, J. G. Ehrenfeld, and M. Haggblom, "Exotic plant species alter the microbial community structure and function in the soil," Ecology, vol. 83, no. 11, pp. 3152-3166, 2002.

[17] S. F. Pei, H. Fu, and C. G. Wan, "Changes in soil properties and vegetation following exclosure and grazing in degraded Alxa desert steppe of Inner Mongolia, China," Agriculture, Ecosystems and Environment, vol. 124, no. 1-2, pp. 33-39, 2008.

[18] G. X. Wang and G. D. Chen, "Characteristics of grassland and ecological changes of vegetations in the Source Regions of Yangtze and Yellow Rivers," Journal of Desert Research, vol. 21, pp. 101-107, 2001.

[19] Y. S. Ma, B. N. Lang, Q. Y. Li, Y. F. Li, and F. J. Li, “The present status of the grassland eco-environment at the headwater areas 
of Qinghai-Tibetan Plateau and resume strategies of degraded grassland," Grassl, vol. 6, pp. 59-61, 1999.

[20] S. K. Dong, L. Wen, L. Zhu, and X. Y. Li, "Implication of coupled natural and human systems in sustainable rangeland ecosystem management in $\mathrm{HKH}$ region," Frontiers of Earth Science in China, vol. 4, no. 1, pp. 42-50, 2010.

[21] L. Christensen, M. B. Coughenour, J. E. Ellis, and Z. Z. Chen, "Vulnerability of the asian typical steppe to grazing and climate change," Climatic Change, vol. 63, no. 3, pp. 351-368, 2004.

[22] K. J. Wessels, S. D. Prince, J. Malherbe, J. Small, P. E. Frost, and D. VanZyl, "Can human-induced land degradation be distinguished from the effects of rainfall variability? A case study in South Africa," Journal of Arid Environments, vol. 68, no. 2, pp. 271-297, 2007.

[23] J. A. Harris, R. J. Hobbs, E. Higgs, and J. Aronson, "Ecological restoration and global climate change," Restoration Ecology, vol. 14, no. 2, pp. 170-176, 2006.

[24] S. K. Allison, "You can't not choose: embracing the role of choice in ecological restoration," Restoration Ecology, vol. 15, no. 4, pp. 601-605, 2007.

[25] C. T. Wang, R. J. Long, Q. L. Wang, W. Liu, Z. C. Jing, and L. I. Zhang, "Fertilization and litter effects on the functional group biomass, species diversity of plants, microbial biomass, and enzyme activity of two alpine meadow communities," Plant and Soil, vol. 331, no. 1, pp. 377-389, 2010.

[26] Y. F. Wang and S. P. Wang, "Influence of different stoking rates on aboveground present biomass and herbage quality on the Inner Mongolia Steppe," Acta Pratacultural Science, vol. 8, pp. 15-20, 1999.

[27] Institute of Soil Science, Chinese Academy of Sciences, The Soil Atlas of China, Cartographic Publication House, Beijing, China, 1986.

[28] S. Lavorel, S. McIntyre, J. Landsberg, and T. D. A. Forbes, "Plant functional classifications: from general groups to specific groups based on response to disturbance," Trends in Ecology and Evolution, vol. 12, no. 12, pp. 474-478, 1997.

[29] Nanjing Institute of Soil Science, Chinese Academy of Sciences, Analysis of Soil Physical-Chemical Feature, Shanghai Science and Technology, Shanghai, China, 1983.

[30] E. D. Vance, P. C. Brookes, and D. S. Jenkinson, "An extraction method for measuring soil microbial biomass C," Soil Biology and Biochemistry, vol. 19, no. 6, pp. 703-707, 1987.

[31] S. Y. Guan, Research Methods on Soil Enzymes, China Agricultural Press, Beijing, China, 1986.

[32] D. S. Powlson, P. C. Prookes, and B. T. Christensen, "Measurement of soil microbial biomass provides an early indication of changes in total soil organic matter due to straw incorporation," Soil Biology and Biochemistry, vol. 19, no. 2, pp. 159-164, 1987.

[33] N. Fierer, J. P. Schimel, and P. A. Holden, "Variations in microbial community composition through two soil depth profiles," Soil Biology and Biochemistry, vol. 35, no. 1, pp. 167176, 2003.

[34] J. Skujins, "History of abiontic soil enzyme research," in Soil Enzymes, R. G. Burns, Ed., pp. 1-49, Academic Press, New York, NY, USA, 1978.

[35] K. Hayano and K. Tubaki, "Origin and properties of $\beta$ glucosidase activity of tomato-field soil," Soil Biology and Biochemistry, vol. 17, no. 4, pp. 553-557, 1985.

[36] F. Eivazi and M. A. Tabatabai, "Factors affecting glucosidase and galactosidase activities in soils," Soil Biology and Biochemistry, vol. 22, no. 7, pp. 891-897, 1990.
[37] G. Rodriguez-Loinaza, M. Onaindiaa, I. Amezagaa, I. Mijangosb, and C. Garbisub, "Relationship between vegetation diversity and soil functional diversity in native mixed-oak forests," Soil Biology and Biochemistry, vol. 40, pp. 49-60, 2008.

[38] R. P. Dick, P. E. Rasmussen, and E. A. Kerle, "Influence of longterm residue management on soil enzyme activity in relation to soil chemical properties of a wheat-fallow system," Biology and Fertility of Soils, vol. 6, pp. 159-164, 1988.

[39] S. P. Deng and M. A. Tabatabai, "Effect of tillage and residue management on enzyme activities in soils: III. Phosphatases and arylsulfatase," Biology and Fertility of Soils, vol. 24, no. 2, pp. 141-146, 1997.

[40] K. A. Dwire, J. B. Kauffman, E. N. J. Brookshire, and J. E. Baham, "Plant biomass and species composition along an environmental gradient in montane riparian meadows," Oecologia, vol. 139, no. 2, pp. 309-317, 2004.

[41] D. Tilman, J. Knops, D. Wedin, P. B. Reich, M. Ritchie, and E. Siemann, "The influence of functional diversity and composition on ecosystem processes," Science, vol. 277, no. 5330, pp. 1300-1302, 1997.

[42] D. Tilman, P. B. Reich, J. Knops, D. Wedin, T. Mielke, and C. Lehman, "Diversity and productivity in a long-term grassland experiment," Science, vol. 294, no. 5543, pp. 843-845, 2001.

[43] C. T. Wang, R. J. Long, and L. M. Ding, "The effects of differences in functional group diversity and composition on plant community productivity in four types of alpine meadow communities," Biodiversity Science, vol. 12, pp. 403-409, 2004.

[44] C. T. Wang, R. J. Long, Q. J. Wang, L. M. Ding, and M. P. Wang, "Effects of altitude on plant-species diversity and productivity in an alpine meadow, Qinghai-Tibetan plateau," Australian Journal of Botany, vol. 55, no. 2, pp. 110-117, 2007.

[45] D. R. Morse, J. H. Lawton, M. M. Dodson, and M. H. Williamson, "Fractal dimension of vegetation and the distribution of arthropod body lengths," Nature, vol. 314, no. 6013, pp. 731-733, 1985.

[46] C. T. Wang, G. M. Cao, Q. L. Wang, Z. C. Jing, L. M. Ding, and R. J. Long, "Changes in plant biomass and species composition of alpine Kobresia meadows along altitudinal gradient on the Qinghai-Tibetan Plateau," Science in China, Series C, vol. 51, no. 1, pp. 86-94, 2008.

[47] F. Berendse, "Interspecific competition and niche differentiation between Plantago lanceolata and Anthoxanthum odoratum in a natural hayfield," Journal of Ecology, vol. 71, no. 2, pp. 379-390, 1983.

[48] R. A. Farley and A. H. Fitter, "The responses of seven co-occurring woodland herbaceous perennials to localized nutrient-rich patches," Journal of Ecology, vol. 87, no. 5, pp. 849-859, 1999.

[49] A. Nordin, P. Högberg, and T. Näsholm, "Soil nitrogen form and plant nitrogen uptake along a boreal forest productivity gradient," Oecologia, vol. 129, no. 1, pp. 125-132, 2001.

[50] T. Tabatabai and W. A. Dick, "Enzymes in soil," in Enzymes in the Environment, R. G. Burns and R. P. Dick, Eds., pp. 567-596, Marcel Dekker, New York, NY, USA, 2002.

[51] B. A. Caldwell, "Enzyme activities as a component of soil biodiversity: a review," Pedobiologia, vol. 49, no. 6, pp. 637644, 2005.

[52] L. C. Broughton and K. L. Gross, "Patterns of diversity in plant and soil microbial communities along a productivity gradient in a Michigan old-field," Oecologia, vol. 125, no. 3, pp. 420427, 2000. 

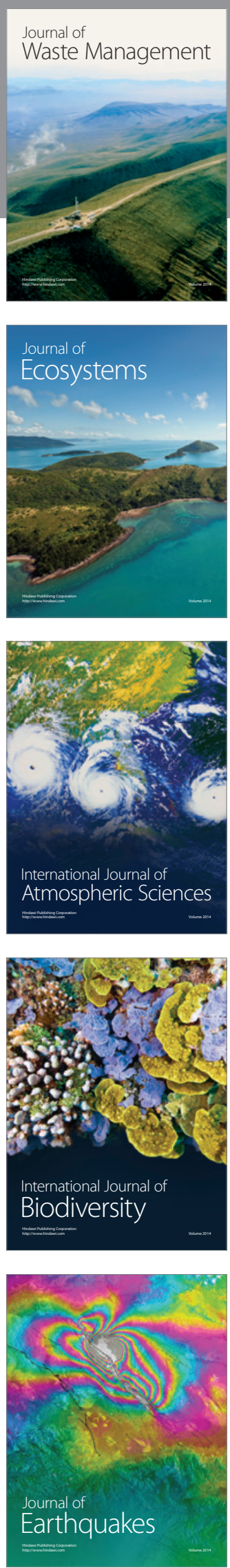
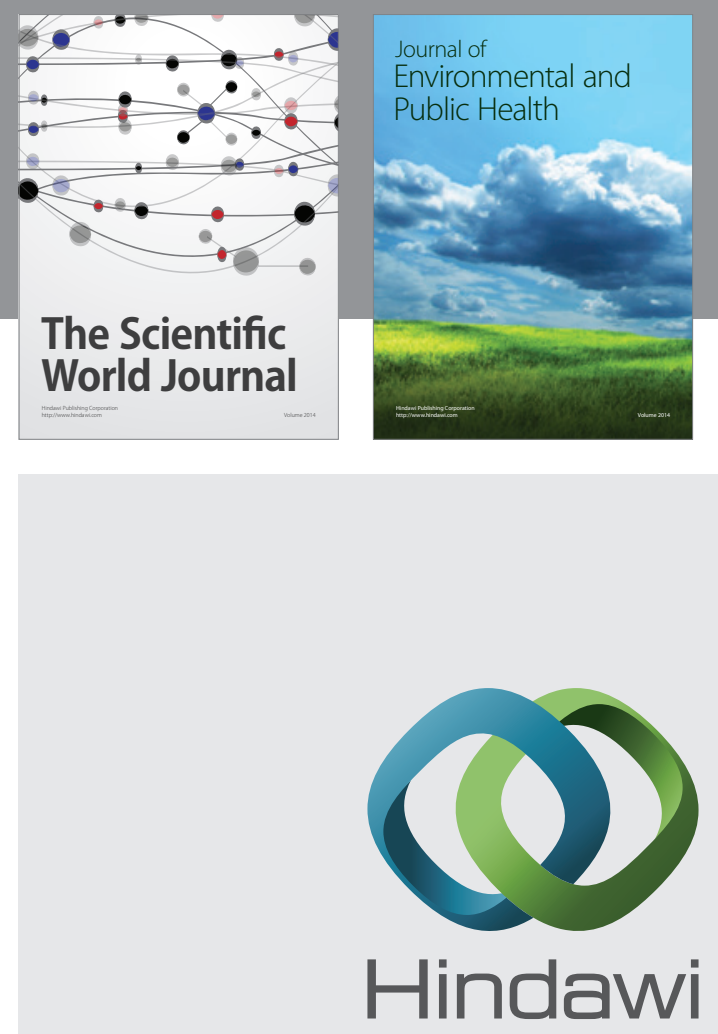

Submit your manuscripts at

http://www.hindawi.com
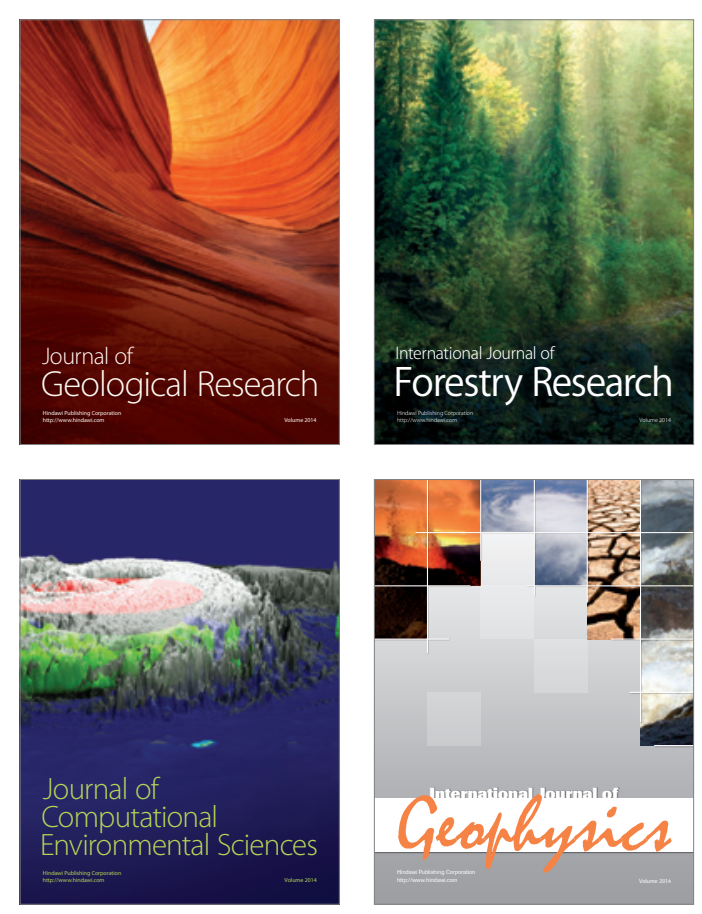
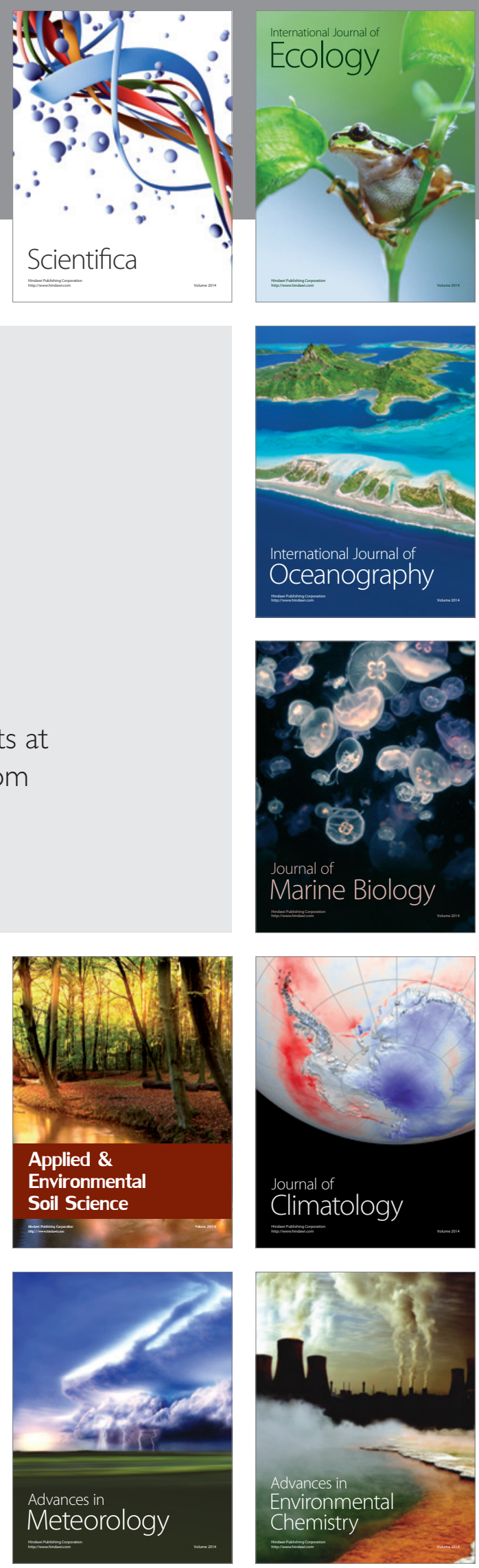